\title{
From Global to Local and Vice Versa: On the Importance of the 'Globalization' Agenda in Continental Groundwater Research and Policy-Making
}

\author{
Viachaslau Filimonau ${ }^{1} \cdot$ Johannes A. C. Barth ${ }^{2}$
}

Received: 20 May 2015/Accepted: 8 June 2016/Published online: 18 June 2016

(c) The Author(s) 2016. This article is published with open access at Springerlink.com

\begin{abstract}
Groundwater is one of the most important environmental resources and its use continuously rises globally for industrial, agricultural, and drinking water supply purposes. Because of its importance, more knowledge about the volume of usable groundwater is necessary to satisfy the global demand. Due to the challenges in quantifying the volume of available global groundwater, studies which aim to assess its magnitude are limited in number. They are further restricted in scope and depth of analysis as, in most cases, they do not explain how the estimates of global groundwater resources have been obtained, what methods have been used to generate the figures and what levels of uncertainty exist. This article reviews the estimates of global groundwater resources. It finds that the level of uncertainty attached to existing numbers often exceeds $100 \%$ and strives to establish the reasons for discrepancy. The outcome of this study outlines the need for a new agenda in water research with a more pronounced focus on groundwater. This new research agenda should aim at enhancing the quality and quantity of data provision on local and regional groundwater stocks and flows. This knowledge enhancement can serve as a basis to improve policy-making on groundwater resources
\end{abstract}

Viachaslau Filimonau

vfilimonau@bournemouth.ac.uk

Johannes A. C. Barth

johannes.barth@fau.de

1 Faculty of Management, Bournemouth University, Talbot Campus, Fern Barrow, Poole, Dorset BH12 5BB, UK

2 Department of Geography and Geosciences, FriedrichAlexander University Erlangen-Nuremberg (FAU), GeoZentrum Nordbayern, Schlossgarten 5, 91054 Erlangen, Germany globally. Research-informed policies will facilitate more effective groundwater management practices to ensure a more rapid progress of the global water sector towards the goal of sustainability.

Keywords Groundwater - Freshwater - Sustainability · Water resources management $\cdot$ Assessment

\section{Introduction}

Groundwater is an increasingly important environmental resource as a large share of global economy and 2.1 billion of people rely on it as the primary source of freshwater (United Nations Children's Fund-UNICEF and World Health Organisation 2012). Nonetheless, the importance of groundwater is often underestimated, while its role in the global and regional water balances is poorly quantified (Gleeson et al. 2015; Llamas 2003; Margat and van der Gun 2013). This is particularly alarming because limited understanding of the groundwater value is attributed not only to the general public, but also to environmental managers and policy-makers, water industry professionals, and academics who work in the field of water resources and environmental management (Lavoie et al. 2013; Margat and van der Gun 2013; Pandey et al. 2011; van der Gun 2012). One reason for this lack of knowledge is that groundwater occurs as an invisible environmental resource (Gleeson et al. 2012). The 'out of sight, out of mind' principle may have determined the yet inadequate attention paid to the issue of groundwater on a global scale.

While groundwater is one of the most widespread environmental resources, its availability does not often match the demand (Gleeson et al. 2012). Given the global significance of groundwater, it is essential to pay more 
attention to the issues of its occurrence, distribution, stocks, and flows (Margat and van der Gun 2013; Wada et al. 2014). It is equally important to educate the general public, industry representatives, policy-makers, and academia about the fragile and complex nature of local, regional, and global groundwater resources. This would enable better protection and facilitate more sustainable consumption and management practices.

The situation is gradually changing and effective groundwater management represents a growing research stream. Recently, particular attention has been paid to the issues of groundwater abstraction, overexploitation, and pollution (Holman and Trawick 2011; Sparks et al. 2015; Wada et al. 2010). There is a general consensus in the literature that reliable estimates of groundwater resources are crucial to tackle these issues (Healy 2010). This is because effective mitigation can only be developed if accurate figures on groundwater stocks and flows become available (Fazal et al. 2001). Furthermore, groundwater represents a cross-boundary resource that can affect significant territories (Margat and van der Gun 2013). Therefore, groundwater quantity and quality assessments should be approached from both, local/regional and global, scales. Despite the challenges attributed to producing a global outlook on groundwater resources, it helps identify major opportunities for management. Global assessments can also be scaled down to regional and local levels (Cash and Moser 2000). This approach follows a key principle of sustainable development 'think globally, act locally,' which suggests that global knowledge is necessary in order to design local mitigation actions (Agenda 21 1992).

A literature review indicates that accurate and reliable figures of global groundwater resources are difficult to obtain. First, there is limited research on global groundwater estimates in general and many studies have focused on surface water, aiming to quantify and assess its global availability (Gleeson et al. 2012, 2015). Second, groundwater research in industrialized countries has more been concerned with the issue of groundwater quality, rather than quantity (Balderacchi et al. 2013). This approach needs rethinking because the problems of groundwater quality and its availability are interlinked and management of the increasing global demand for freshwater will rely on a combination of both (Mays 2013).

Further analysis shows that the available literature often fails to explain how existing estimates of global groundwater resources have been obtained (Margat and van der Gun 2013). In many cases, this is manifested by the fact that figures retrieved from previous studies are taken as a 'given,' without questioning their accuracy and reliability of the original source. Better understanding of how the estimates of global groundwater resources have been produced is crucial as this enables better and more critical assessment of their reliability and facilitates evaluation of the factors that might contribute to uncertainty.

Another important issue is attributed to significant differences between existing figures of global groundwater resources (Margat and van der Gun 2013). This calls for more research on this topic, to help identify the most accurate estimate and outline the pathways to reduce the magnitude of uncertainty. Better understanding of existing estimates of global groundwater resources is vital because accurate values are necessary to foster more sustainable groundwater management practices. They should enhance the effectiveness of water management-related policies globally.

This study aims to demonstrate the global importance of groundwater as an environmental resource by highlighting its role in the global water balance ("Global Water Resources: Defining Stocks and Flows" section). It also strives to discuss its economic and societal value ("Economic and Societal Significance of Global Groundwater Resources" section). The study further reviews existing estimates of global groundwater resources as reported in specialist literature, examines how these have been produced, establishes the range of uncertainty attributed to them, and evaluates the implications for sustainable groundwater management and policy-making ("Global (Ground) Water Estimates: A Critical Review" section). It discusses measures that should be applied to enhance the accuracy of global groundwater estimates and puts forward recommendations for their implementation ("Towards More Effective Management of Groundwater Resources: The Importance of 'Globalization' of Groundwater Research and Policy-Making Agenda” section).

\section{Groundwater as a Pivotal Environmental Resource}

\section{Global Water Resources: Defining Stocks and Flows}

According to Margat and van der Gun (2013), stock is one of the two variables that characterize global water resources. The second variable is flow or the rate of water exchange between water storage compartments. The combination of both is often termed the annual global water balance (Berner and Berner 1996). This paper presents average numbers from a literature review on the global water balance (Fig. 1). While this review strives to be comprehensive, it cannot be considered complete. It is limited to the number of studies that were identified via a search on the citation-based academic search platform, Google Scholar, conducted within the period of 4-7th April 2016. The following search terms were used: global water balance and global groundwater stocks OR flows OR resources. The OR operator enabled inclusion of literature sources that dealt with global groundwater resources in 
Fig. 1 Global water balance, schematic, and not-to-scale. Water stocks are in million $\mathrm{km}^{3}$ and water flows are in million $\mathrm{km}^{3} \mathrm{a}^{-1}$. The key sources for this figure are Berner and Berner (1996), Seiler and Gat (2007), UNEP (2008), and World Business Council for Sustainable DevelopmentWBCSD (2005)

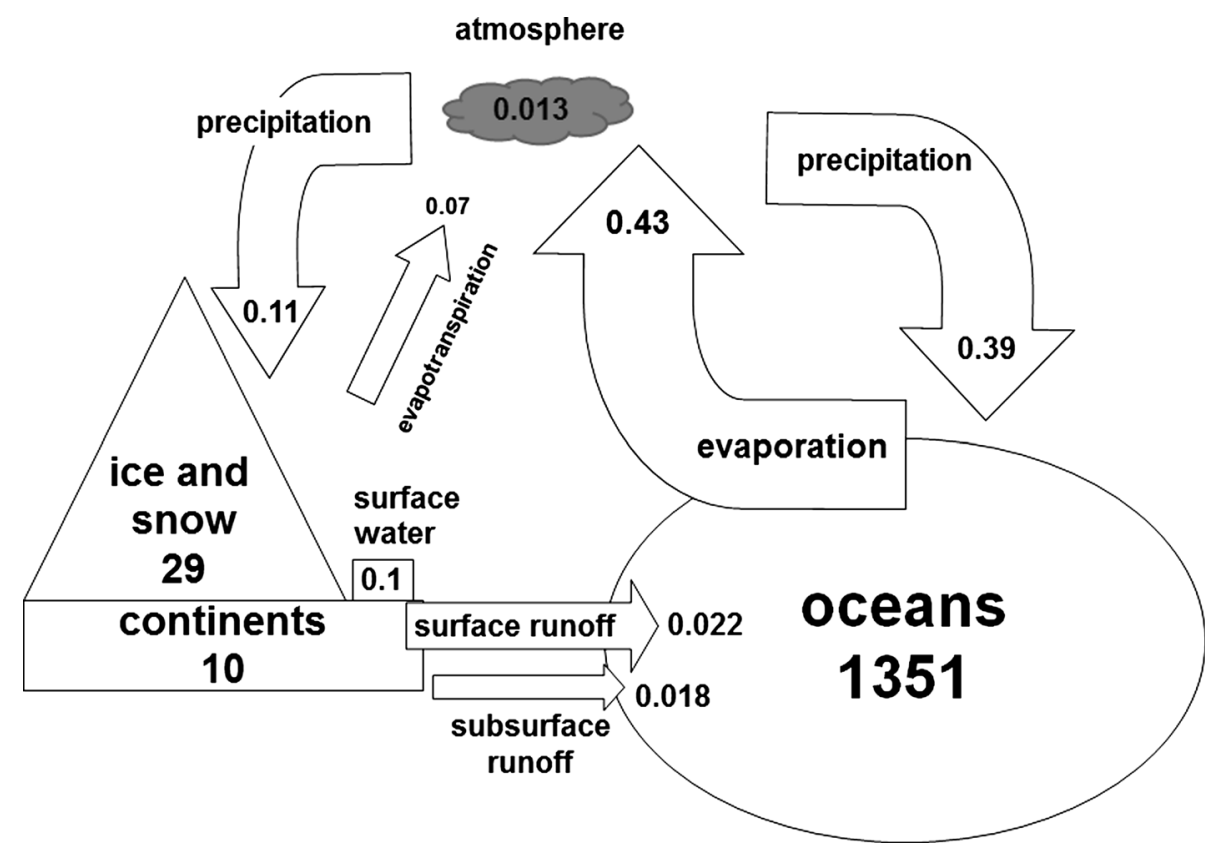

In terms of flows, annual global precipitation represents the largest water flow on Earth with the magnitude of approximately 0.5 million $\mathrm{km}^{3} \mathrm{a}^{-1}$. Almost $80 \%(0.39$ million $\mathrm{km}^{3} \mathrm{a}^{-1}$ ) of this volume is attributed to precipitation over the ocean. Evapotranspiration from land surface is averaged with 0.07 million $\mathrm{km}^{3} \mathrm{a}^{-1}$. Assuming a steadystate system, the difference between continental precipitation and continental evapotranspiration (0.11-0.07 million $\mathrm{km}^{3} \mathrm{a}^{-1}$ ) represents the global runoff from the continents (0.04 million $\left.\mathrm{km}^{3} \mathrm{a}^{-1}\right)$. The global runoff can be subdivided into the surface runoff (estimated as $55 \%$ of the total runoff or 0.022 million $\mathrm{km}^{3} \mathrm{a}^{-1}$ ) and the subsurface runoff that mostly consists of groundwater discharge into the ocean (estimated as $45 \%$ or 0.018 million $\mathrm{km}^{3} \mathrm{a}^{-1}$ ) (Seiler and Gat 2007). The sum of the groundwater and surface water discharge to the ocean $\left(0.04\right.$ million $\left.\mathrm{km}^{3} \mathrm{a}^{-1}\right)$ also makes up the difference between evaporation from the oceans $\left(0.43\right.$ million $\left.\mathrm{km}^{3} \mathrm{a}^{-1}\right)$ and precipitation over the oceans $\left(0.39\right.$ million $\left.\mathrm{km}^{3} \mathrm{a}^{-1}\right)$. The latter closes the cycle of the annual global water balance.

In terms of usability, the volume of global freshwater is of primary interest. While ice and snow represent the key storage compartment for freshwater on Earth and their melt water is a major feed source for global rivers, the direct use of ice and snow is constrained by a number of factors, such as geographical availability. In contrast, groundwater has a more ubiquitous geographical distribution and usually

Footnote 1 continued

source of data. "Global (Ground) Water Estimates: A Critical review" section reviews this issue in detail. The figures cited here are the 'averaged' numbers reported in specialist literature.
1 The estimates of water volumes and flows attributed to each of the
water storage compartments differ considerably depending on the 
requires little treatment before its use. This underlines the strategic importance of groundwater as a global freshwater stock.

\section{Economic and Societal Significance of Global Groundwater Resources}

Globally, groundwater represents a vital environmental resource, both in terms of stocks and flows. From the utility point of view, the role of groundwater is equally important. With the annual abstraction rate of about 0.001 million $\mathrm{km}^{3}$ in 2010, it accounts for about $25 \%$ of the annual global freshwater withdrawal (UNESCO 2012). Worldwide, this makes groundwater the most used environmental resource, ahead of gravel, coal, and crude oil (Zektser and Everett 2004)

Global freshwater withdrawal is predicted to grow in order to meet the rising demands from the industry, agriculture and households (Alcamo et al. 2003; Wada et al. 2010). For instance, the numbers by UNESCO (2012) suggest that, in 2011, the volume of freshwater withdrawn globally had reached 0.004 million $\mathrm{km}^{3}$. For comparison, this amount was equivalent to approximately $17 \%$ of the volume of Lake Baikal, the world's largest open freshwater reservoir, with a volume of about 0.024 million $\mathrm{km}^{3}$. In 2025, annual global freshwater withdrawals are predicted to reach about 0.005 million $\mathrm{km}^{3}$ (Seiler and Gat 2007; Shiklomanov and Rodda 2003; WBCSD 2005). This number corresponds to about $21 \%$ of the volume of Lake Baikal. By 2050, the global demand for freshwater is expected to grow up to 0.012 million $\mathrm{km}^{3}$ (Nature 2008) which is equivalent to the volume of Lake Superior or about $50 \%$ of the volume of Lake Baikal. Importantly, the relative contribution of groundwater abstraction to global freshwater withdrawals may also grow due to the increasingly high dependence of the world population and global economy on groundwater resources (Wada et al. 2010, 2014).

The current figures of global fresh- and groundwater withdrawals indicate that they do not exceed the magnitude of the annual global freshwater $\left(0.04\right.$ million $\left.\mathrm{km}^{3} \mathrm{a}^{-1}\right)$ and groundwater $\left(0.018\right.$ million $\left.\mathrm{km}^{3} \mathrm{a}^{-1}\right)$ flow. This also holds true for future projections up to 2050 (UNESCO 2012; Wada et al. 2010). These figures do not however indicate the differences in annual groundwater withdrawals across the world. They should therefore be taken with caution as they may lead to the incorrect conclusion that there is enough useable groundwater everywhere. This is not true because the volumes of the groundwater withdrawn have significant geographical variations and in many arid regions the magnitude of groundwater withdrawals exceeds the rates of the annual groundwater renewal (Goldenberg 2014). This often implies unsustainable groundwater management that may lead to long-term detrimental environmental and socio-economic effects.

In terms of economic and societal role, Foster and Chilton (2003) stated that groundwater globally provides about $50 \%$ of drinking water, $40 \%$ of industrial water, and $20 \%$ of the water used for irrigation. In a more recent study, Margat and van der Gun (2013) provide different figures which suggest that $70 \%$ of all groundwater abstracted in the world is intended for irrigation, $21 \%$ for domestic use (which includes drinking water), and $9 \%$ for industrial purposes. This discrepancy may be partially attributed to the variations in methodological approaches that were applied to calculate the share of groundwater. It is more likely, however, that it arises due to the lack of monitoring of groundwater extraction across the world, especially in developing countries, which hampers derivation of accurate estimates globally. This underlines the issue of insufficient attention paid to groundwater in research and policy-making, both at a local/regional and a global scale.

According to UNICEF and the World Health Organisation (2012), today about $30 \%$ of the world's population relies on groundwater with expected rapid growth in the future. The above emphasises the necessity to pay closer attention to groundwater stocks and flows. In a first instance, this should aim to produce more accurate numbers of local and regional stocks and their associated flows. A second step should aim to comprehend the magnitude of local and regional extractions with subsequent reinforcements of sustainable extraction levels.

In summary, although annual global freshwater and groundwater withdrawals do not exceed the rates of the annual freshwater flow and large reservoirs of freshwater exist, projected shortages of available good-quality freshwater are expected to intensify in the future (see, for example, UNEP 2008). This is because freshwater replenishment, flows, and stocks are unevenly distributed on Earth. While arid regions suffer most, even the areas with sufficient water renewal rates may increasingly become affected by water shortages if the hygienic and chemical quality of water deteriorates. In addition, the global demand for freshwater is likely to increase in the future due to the population growth, agricultural, and industrial development and the overall rise of living standards among the population. Among available water resources, groundwater currently represents the most plausible water resource for consumption as it is fairly easy to access, relatively inexpensive to mine and often requires little or no further treatment. Better understanding of how much groundwater can be withdrawn without imposing a detrimental effect on the environment is essential. A fundamental prerequisite for this aim is the accurate figures on globally available groundwater stocks and flows. 


\section{Global (Ground)Water Estimates: A Critical Review}

Analysis of literature shows that the number of original estimates of global (ground)water stocks and flows is limited by the figures reported in a handful of studies (Table 1). Most of the sources reviewed do not clarify how the estimates have been produced. Furthermore, many of the figures cited are taken for 'granted' from past research.

Further analysis reveals significant uncertainties across the estimates (Table 1). It suggests that, when a normal distribution is assumed, among all elements of the global water balance, the level of uncertainty lies within a $10 \%$ range only for the estimates of water stored in the oceans (Table 1). This is largely because the volume of surface water-containing reservoirs should be fairly easy to calculate given the ongoing advancements in geophysical and echosound methods (see, for example, Charette and Smith 2010).

In contrast, the water flows partaking in the global water balance in the form of precipitation and evapotranspiration alongside the volume of the water stored in the atmosphere are characterized by considerably higher levels of uncertainty of up to $30 \%$ (Table 1, marked in light grey). This is primarily due to the fact that the accurate evaluations of precipitation and evaporation over the oceans are hardly possible, which results in higher uncertainties (Joyce et al. 2004). Uncertainties in assessing the magnitude of the water stored in the atmosphere may also be attributed to the difficulties in determining its volume because of short residence times (Berner and Berner 1996).

Further analysis shows that the estimates of water stored in the form of ice and snow as well as surface- and groundwater runoff from the continents (combined) have higher uncertainties (Table 1, marked in medium-spectre grey). Here, the surface runoff from the continents is only estimated for the largest rivers that have gauging stations. Smaller rivers, which in sum discharge considerable amounts of water to the oceans, are often not taken into account and this contributes to uncertainty (Berner and Berner 1996). This is because smaller rivers do not always host gauging stations (Verdin and Verdin 1999); furthermore, they may not necessarily provide sufficiently long and detailed discharge records, particularly in developing countries and remote regions, such as those adjacent to the Arctic Ocean (Peterson et al. 2002).

Most importantly, the estimates of global groundwater stocks and its runoff from the continents to the ocean are characterized by uncertainties of over $100 \%$ (Table 1 , marked in dark grey). It is further worth mentioning that only three literature sources $(0.3 \%)$ from the 1000 reviewed Google Scholar search results have provided figures on the groundwater runoff from the continents. This shows that global groundwater stocks and its runoff are the elements of the global water balance that remain difficult to quantify and their poor visibility and limited access make significant impacts on the accuracy of their assessment. The high levels of uncertainty attributed to these elements of the global water balance are of particular concern given the critical socio-economic role of increasing water use for irrigation, households, and the industry. Notably, some figures of global groundwater stocks vary considerably from the rest (i.e. 23.4 and 22.6 (21.97) million $\mathrm{km}^{3}$, Table 1). Closer analysis shows that this is because these larger numbers incorporate both saline- and fresh groundwater and do not differentiate between these two types of groundwater. This may lead to the incorrect conclusions about the magnitude of globally useable groundwater resources. It is argued that this figure should be revisited to display the amount of fresh groundwater only given that such references as UNEP publications are often used as key data sources by academics and non-academics, also from outside the field of groundwater resources management. However, even when the larger estimates of global groundwater stocks including saline- and freshwater are removed, the level of uncertainty attributed to this element of the global water balance remains at about $90 \%$. Significant uncertainty established for the estimates of global fresh groundwater stocks and flows can be attributed to the following factors.

First, some of the figures originate from the literature sources published from 1970 to 1990 . This is also confirmed by the most recent analyses by Gleeson et al. (2015). The accuracy of groundwater assessment methods at the time may have been insufficient. This can partially explain the different numbers of global groundwater stocks associated with these sources. Nonetheless, authors such as Lvovitch (1970), Nace (1971), and Van der Leeden (1975) also serve as references in more recent studies on the global water balance (e.g. Linton 2004). In order to avoid incorrect conclusions regarding the magnitude of global groundwater stocks, future references should be given to more recent studies that are based on more advanced methods of assessment, such as modelling and remote sensing (see Sect. 3.1 Methods to produce the estimates of global groundwater stocks and flows: an overview).

Second, the high levels of discrepancy among more recent figures on global groundwater stocks and flows may result from the complexity of groundwater systems whose extent is difficult to measure. This includes hydrogeological characteristics of the surface and subsurface waters, climatic, and atmospheric processes and water regimes of surface water storage bodies (Balek 1989; Freeze and Cherry 1979; Polak et al. 2007; Seiler and Gat 2007). For example, large discrepancies exist in volumetric evaluations of the water stored in the subsurface when only visible piezometers and well 
data are used. This also holds true when high-resolution geophysical techniques are used because they often have limited spatial ranges of application, such as at the level of river basins (Günter et al. 2007a). Furthermore, data on groundwater recharge and subsurface runoff are sparse and can only be determined with hydrogeological gradients and control planes. This is especially difficult in developing countries that often have insufficient resources to deploy and maintain measurement networks of groundwater observation wells (Frimpong et al. 2003).

Third, the estimates of groundwater discharge to surface waters, particularly from coastal aquifers to the ocean, often rely on the numbers that represent the difference between the continental recharge via precipitation and the discharge via large rivers (Sophocleous 2002). Moreover, while groundwater is deemed to be present in the subsurface up to the depth of several kilometres, it can be considered as useable only to a few hundred metres (Berner and Berner 1996; Margat and van der Gun 2013). Beyond this depth, efforts for abstraction often render groundwater use uneconomic as the extraction costs alongside salinities increase. However, exact critical depths for groundwater use are difficult to determine. They often have significant geographical variations and show challenges in the assessment of pore space in aquifers. Likewise, while useable groundwater resources may exist beneath the ocean floor, little is known about their magnitude (Post et al. 2013; van Geldern et al. 2013).

Lastly, while the global water balance is predominantly controlled by natural factors such as evaporation, transpiration, precipitation, and runoff, recently human-induced impacts have also been influencing global groundwater stocks and flows. On larger scales, this occurs indirectly through the acceleration of climatic changes. Locally and regionally, the effect can be made through the reshaping of waterways (e.g. via damming, river channelling, and

Table 1 Estimates of flows and stocks within the different elements of the annual global water balance as reported in literature

\begin{tabular}{|c|c|c|c|c|c|c|c|c|c|c|c|}
\hline Literature Source & 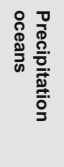 & 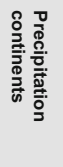 & 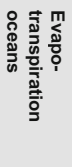 & 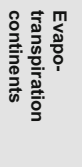 & 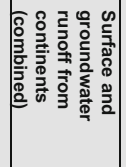 & 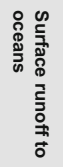 & 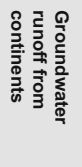 & 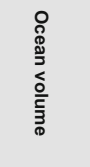 & 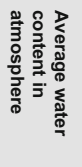 & 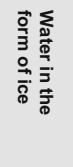 & 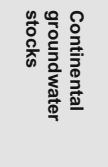 \\
\hline Alley et al. (2002) & 0.385 & 0.111 & 0.425 & 0.071 & & 0.04 & & 1350 & 0.013 & 33 & 15.3 \\
\hline Berner and Berner (1996) & 0.4 & 0.1 & 0.4 & 0.06 & 0.04 & & & 1400 & 0.01 & 48 & 15.3 \\
\hline Gleick (1993) & & & & & & & & & & & 23.4 \\
\hline Jones (1997) & & & & & & & & & & & 8.2 \\
\hline Lvovitch (1970) & & & & & & & & & & & 4 \\
\hline Marcinek et al. (1996) & 0.359 & 0.122 & 0.384 & 0.097 & & & & & & & \\
\hline Margat and van der Gun (2013) & & & & & & & & & & & 10 \\
\hline Mook and de Vries (2000) & 0.385 & 0.111 & 0.425 & 0.071 & 0.04 & & & 1350 & 0.0155 & 27.8 & 8 \\
\hline Nace (1971) & & & & & & & & & & & 6 \\
\hline Oki et al. (2005) & 0.391 & 0.111 & 0.437 & 0.066 & 0.076 & 0.046 & 0.03 & 1338 & 0.013 & 24.1 & 23.4 \\
\hline Schwartz and Zhang (2003) & & & & & & & & & & & 8.34 \\
\hline Seiler and Gat (2007) & 0.46 & 0.11 & 0.5 & 0.065 & 0.045 & 0.027 & 0.018 & 1351 & 0.013 & 27 & 8 \\
\hline Shiklomanov $(1996 ; 1997)$ & & & & & & & & & & & 10.55 \\
\hline Shiklomanov and Rodda (2003) & & & & & & & & & & & 23.4 \\
\hline UNEP (2008) & 0.46 & 0.119 & 0.5 & 0.074 & 0.045 & 0.043 & 0.002 & 1365 & & 32.9 & 23.4 \\
\hline UNESCO (2003) & & & & & & & & & & & 10 \\
\hline van der Leeden (1975) & 0.32 & 0.1 & 0.35 & 0.07 & 0.04 & & & 1320 & 0.013 & 29.2 & 8.35 \\
\hline Widen-Nilsson et al. (2007) & & & & & & 0.039 & & & & & \\
\hline Gleeson et al. (2015) & & & & & & & & & & & $22.6(21.97)$ \\
\hline Mean & 0.395 & 0.111 & 0.428 & 0.072 & 0.048 & 0.039 & 0.017 & 1353.429 & 0.013 & 31.714 & 13.426 \\
\hline 1 sigma (65 confidence) & 0.044 & 0.007 & 0.049 & 0.010 & 0.013 & 0.006 & 0.011 & 22.952 & 0.002 & 7.272 & 6.871 \\
\hline 2 sigma (95 confidence) & 0.088 & 0.015 & 0.098 & 0.021 & 0.026 & 0.013 & 0.023 & 45.905 & 0.003 & 14.543 & 13.743 \\
\hline percentage of 2 sigma with respect to mean & 22.4 & 13.2 & 23.0 & 29.0 & 54.0 & 33.2 & 137.6 & 3.4 & 24.7 & 45.9 & 102.4 \\
\hline
\end{tabular}

Numbers are in million $\mathrm{km}^{3} \mathrm{a}^{-1}$ for flows and in million $\mathrm{km}^{3}$ for stocks. Note that recent work by Gleeson et al. (2015) also differentiates groundwater ages 
subsurface constructions), groundwater abstraction, irrigation, or by the reinjection of water into aquifers. To date, the impact of these factors on the global water balance has been difficult to quantify, especially in the long term. However, a number of examples demonstrate a detrimental effect of human activities on global (ground)water quantity, quality, and dynamics (Diamond 2005). These impacts are expected to intensify with population growth and therefore call for more attention. This is particularly important for groundwater whose capability to replenish is limited due to slow annual flows, long memory effects, and anticipated greater use.

\section{Methods to Produce the Estimates of Global Groundwater Stocks and Flows: An Overview}

Analysis of the estimates of global groundwater stocks and flows demonstrates that most literature sources do not report on the methods used for assessment of global groundwater resources. The lack of this information hampers critical evaluation of the reliability of the figures provided. Subsequent analysis of specialist literature was undertaken to establish how the estimates of global groundwater stocks and flows have been obtained with a view to reveal the key methods applied for assessment. The following methods have been identified: simplified volume calculations, modelling, remote sensing, geographic information systems (GIS), geophysical and geochemical (i.e. isotope) techniques, and surface water discharge determinations.

The primary method for estimating global groundwater stocks, which many of the subsequent studies have relied upon, was developed by Shiklomanov (1996, 1997). It generates a figure of groundwater stocks for each continent (except for Antarctica) by multiplying the total area of the continent by the estimated groundwater depth, a water loss factor, and the effective porosity (Jacobson 2000; Shiklomanov and Rodda 2003). A critical question for this method is to define the depth of groundwater storage that depends on a number of factors, such as hydrogeological structure, recharge hydrodynamics, rock types, and geothermal gradients. For example, porosity can only be roughly estimated, and not accurately measured, due to the small-scale complexity of the geological formations in the subsurface (Arnell 2002). Otherwise, it can also be determined in pumping tests the application of which is however mostly limited to the depth of several dozens of metres (Massmann and Madden 1994).

The maximum estimated depth of groundwater storage is taken by Shiklomanov $(1996,1997)$ as $2000 \mathrm{~m}$. For this depth, the three zones of groundwater storage are distinguished on the basis of the differences in hydrodynamics. These zones are attributed different values of effective porosity that range from $5 \%$, for the lowest, to $15 \%$, for the uppermost, layer. Reflecting the differences in porosity, the uppermost zone of the subsurface across the globe stores 3.6 million $\mathrm{km}^{3}$, the intermediate depth zone accommodates 6.2 million $\mathrm{km}^{3}$ and the lowest zone hosts 13.6 million $\mathrm{km}^{3}$ of groundwater. When combined, this yields a total of 23.4 million $\mathrm{km}^{3}$. Shiklomanov $(1996,1997)$ further differentiates between saline and fresh groundwater stocks; the latter are estimated as 10.5 million $\mathrm{km}^{3}$; however, no explanation is provided on how this figure is obtained. While the estimates by Shiklomanov (1996, 1997) have been the basis for many subsequent studies on global groundwater stocks, it is important to recognize that significant changes have occurred since 1997 in terms of the methods developed to determine porosity values and define water loss factors. The latter may have been affected by climate change and humaninduced impacts. This calls for the refinement of the method by Shiklomanov $(1996,1997)$ with a view to enhance its accuracy and generate more precise numbers of global groundwater stocks.

Newer estimates of global groundwater resources, particularly flows, are predominantly generated via models where the WaterGAP Global Hydrology Model (Döll et al. 2003), the Global Energy and Water Cycle Experiment Project (Potter and Colman 2003), and The Global Soil Wetness Project (Oki et al. 2005) represent the key analytical platforms. These approaches to groundwater assessment have their own uncertainties. For example, they assume that climate parameters are stationary. This means that the climatic patterns observed in the past will also hold true in the future with insignificant variations (Gleick 1993). This assumption cannot always be made with natural water dynamics and accelerated climatic changes. Groundwater assessments should ideally rely on continuous and dense data of geological, hydrological, and meteorological parameters which are essential for model calibration (Dragoni and Sukhija 2008; Shiklomanov and Rodda 2003). Such data can be difficult to compile on a global level, hence the local and regional focus becomes paramount. For instance, calibration of the WaterGAP model is based on the data that, currently, cover only $50 \%$ of the global land area and $70 \%$ of the actively discharging area (Döll and Fiedler 2008), which contributes to uncertainty. Most importantly, many large-scale hydrological models such as those by Arnell (1999), Klepper and van Drecht (1998), and Yates (1997) focus primarily on atmospheric and land surface waters and largely ignore groundwater. In these models, groundwater stocks and flows are usually treated as a residual element that therefore receives little attention.

Recently, remote sensing techniques have found increased application to evaluate the magnitude of spatial 
and temporal variations in water storage and flows on Earth. For example, the Gravity Recovery and Climate Experiment (GRACE) twin satellite project was initiated in 2002 (Rodell and Famiglietti 2002). It aims at monitoring changes in water storage in aquifers on a monthly basis and mapping their spatial distribution (Günter et al. 2007a,b; Jin and Feng 2014). The key feature of GRACE is its capability to establish the magnitudes of variations. Hence, it is best applied to assess the relative changes in water storage, such as the volume of the global groundwater recharge and discharge rates (Jin and Feng 2014). The capability of GRACE to provide absolute estimates of the water stored in different compartments of the global water balance is limited. Analysis of the literature indicates that it has not yet been utilized to specifically assess the magnitude of global groundwater stocks and flows. Furthermore, the project is still under development and its measurements are expensive (Günter et al. 2007b; Jin and Feng 2014). Lastly, the capability of GRACE to estimate short-term variations in water stocks and flows is limited. This may cause systematic errors due to tides, wave motion or fluctuations in global soil moisture (Günter et al. 2007a). This may diminish its value when applied on a local and a regional scale.

A number of studies rely on GIS application to groundwater-related issues, including assessments of groundwater resources. The primary focus of these studies is on local and regional scales (see, for example, Chen et al. 2005; Rahman 2008). Globally, the GIS method has been applied within the scope of the Worldwide Hydrogeological Mapping and Assessment Programme (WHYMAP) and the International Groundwater Resources Assessment Center (IGRAC) (2015) (Struckmeier and Richts 2006). These projects are mainly concerned with providing better visualization of the outcome of smaller scale studies on the assessment of groundwater stocks. They do not however quantify or model the magnitude of global groundwater resources (IGRAC 2015; Struckmeier and Richts 2006, 2008). The GISbased assessments of groundwater stocks and flows depend on reliable and high-frequency input data on surface and aquifer systems. Input of such localized and regionalized data often requires significant data mining and programming skills (Welsh 2007) which can be expensive and labour intense.

Recent work by Gleeson et al. (2015) used global distributions of siliciclastic, carbonate, volcanic, and crystalline rocks. They were plotted with their estimated porosity distribution versus depth to estimate groundwater volumes stored in the continental crust. They further used tritium data and two-dimensional models to outline groundwater ages of $25,50,75$, and 100 years with the volumes of $0.19,0.35,0.45$, and 0.63 million $\mathrm{km}^{3}$, respectively. This shows that the largest part of continental groundwater (i.e. 21.97 million $\mathrm{km}^{3}$ ) has ages of over 100 years and thus likely higher salinities.

In summary, several methods have been applied to produce estimates of global groundwater resources. The key limitation of these methods is that none of them have been developed to specifically address the groundwater issues and their focus has been on surface water stocks and flows. This calls for a change, given the increasingly significant role played by groundwater in global society and economy. It is argued that new and combined efforts need to be developed to raise the position of groundwater on political, societal, and research agendas. Existing estimates of global groundwater stocks and flows are characterized by significant levels of uncertainty and there is a clear need for more accurate assessments to ensure the development of more sustainable groundwater consumption and management practices. These assessments are best to be carried out at local and regional scales with subsequent scaling up to inform the international groundwater research and policy-making agenda.

\section{Towards More Effective Management of Groundwater Resources: The Importance of 'Globalization' of Groundwater Research and Policy-Making Agenda}

The above analysis indicates that there is a need for a new and more groundwater-focused research agenda that should aim at enhancing data reliability on global groundwater resources. This can in part be achieved via the joint application of the most accurate and up-to-date methods of assessment. The approach adapted in some studies, which prioritizes surface waters, while treating groundwater as a residual element of analysis needs revision. Likewise, the approaches that concentrate on the evaluation of groundwater quality rather than quantity should be revisited.

The concept of 'globalization' should be closely integrated into groundwater research and policy-making. Here, the most reliable estimates of groundwater stocks and flows can be derived at local and regional scales. The extensive databases of local and regional data on groundwater should be developed and then utilized to inform research and policy-making agenda internationally. To this end, there is a need for close intra-country and intra-regional research collaboration on the topic of assessment of groundwater resources as aquifers rarely do align with national borders. Given that this relates to a number of political and social issues, the new research agenda should be interdisciplinary in nature and aim to unite experts from the political, socioeconomic, and environmental dimensions. 


\section{Global Groundwater Data: Access and Retrieval}

There is a need for more empirical studies that enhance the quality of data on global groundwater. Margat and van der Gun (2013) claim that these data are difficult to access across the world which hampers any comparative analysis of the volumes of the abstracted groundwater against available stocks and flows. For instance, some countries restrict access to groundwater data as they are considered of strategic importance (Jha and Chowdary 2007; Kumar 2002). Open access to groundwater data for research purposes should be facilitated globally. Furthermore, it is essential to obtain more data on how the abstracted groundwater is used. For instance, Wada et al. (2010) find that significant amounts of the abstracted groundwater globally are lost due to ineffective storage and treatment.

Holistic data on subsurface porosity are vital to more accurately determine the depth of groundwater occurrence (Arnell 2002). It is argued that the studies on porosity are best conducted at a smaller scale to improve accuracy. Likewise, literature review outlines the necessity to retrieve more data on the groundwater recharge and subsurface runoff (Margat and van der Gun 2013). Values on recharge and runoff are important for better understanding of how much groundwater can be abstracted without imposing a detrimental effect on its stocks. Research on this topic should start at smaller scales to ensure better data accuracy.

The volumes of usable groundwater internationally are restricted by quality which, in turn, depends on salinity, pollution, and, in some cases, hardness. Hence, new research agenda should supply reliable, detailed data on these topics, preferably extracted locally and then combined into detailed, global databases (Margat and van der Gun 2013). In addition, more studies should address the issue of interaction and exchange between surface- and groundwater as its magnitude can be significant but yet poorly understood (Palakodeti et al. 2009; Wada et al. 2010). The topics of groundwater quality and groundwater interaction with surface water bodies are interrelated as, for instance, sea water can penetrate groundwater stocks in coastal regions, thus negatively affecting their quality.

More research is also required in the areas that are traditionally seen as well explored, but prove to be insufficiently examined at closer analysis. For instance, the geography of global groundwater distribution calls for more comprehensive understanding (Margat and van der Gun 2013), especially in the context of groundwater stocks that occur under the ocean floor. The study by Post et al. (2013) indicates that these can be significant and should be included into the estimates of global groundwater resources. Likewise, Antarctica needs to be integrated into global groundwater assessments. While this continent has traditionally been excluded from analysis (see, for example, Shiklomanov 1997); recently, there has been evidence to suggest that Antarctica may host significant volumes of groundwater (Christoffersen et al. 2014), thus calling for more in-depth evaluation. While knowledge on the amount of groundwater stored under the ocean floor and in Antarctica is paramount for academic purposes, it is also significant from the practical standpoint as this groundwater can be considered a strategic global reserve and may exert so far unknown influences on climate change.

Furthermore, given the growing anthropogenic footprint on global water resources (Gleeson et al. 2012; Vörösmarty et al. 2004), it is vital to better understand the scope and the magnitude of man-made impacts on global groundwater. The new, previously unknown effects should be diligently researched. For instance, new evidence shows that hydraulic fracturing or fracking may have significant detrimental impacts on groundwater quantity and quality (Gordalla et al. 2013; Jackson et al. 2013; Stuart 2011) and these should therefore be examined in more detail given that the shale gas extraction is currently underway across the world (Hughes 2013).

Lastly, it is essential to better understand how the issue of climate change may affect the occurrence, distribution, and quality of global groundwater stocks and flows. While this area represents a growing research field, more studies are necessary. Detailed knowledge on this topic should help develop more effective adaptation and mitigation (Green et al. 2011; Pandey et al. 2011). Better understanding of the role played by global groundwater in the transition to a low-carbon economy is of particular importance (Younger 2014). For instance, the impact of biofuel production on global groundwater systems has been acknowledged but little is known about its magnitude and therefore more research is required (Uhlenbrook 2007).

\section{Global Groundwater: Enhancement of the Methodological Base}

Reliable methods play a crucial role in obtaining accurate data on global groundwater resources. It is argued that a new, 'globalized' research agenda should strive to promote application of reliable groundwater assessment techniques that have proven their potential in generating good-quality data at affordable costs. For example, more research is necessary on how the methods effectively utilized in soil mechanics could be adapted for making estimates of groundwater stocks and flows. The application of these methods should provide more accurate and reliable data on groundwater occurrence and dynamics. Furthermore, further isotope analysis can be used to supplement the techniques applied in soil mechanics. As shown by van Geldern 
et al. (2014), such techniques can help generate numbers on yet poorly quantified occurrences of groundwater, for instance under the ocean floor, thus contributing to more accurate assessments of groundwater stocks locally, regionally, and then globally.

The remote sensing approaches, such as GRACE (Rodell and Famiglietti 2002), have the potential to generate accurate estimates of variations in the volume of water storage compartments across the globe. The outcome can be used by modelling studies to obtain more reliable estimates on local and regional groundwater resources that, when combined, will derive a global picture. Similar to the case of data retrieval and access, it is argued that research on the application of different methods and techniques should first be conducted at smaller scales. Subsequent upscaling and assembly of smaller studies can enable larger outlooks. Collaboration between geophysics, geochemistry, and modelling can enhance the methodological base of the studies on groundwater resources and improve the overall accuracy of groundwater estimates.

\section{Global Groundwater: Research to Enhance Policy-Making}

The literature review showed that the outcome of groundwater studies is yet insufficiently embedded into policyplanning. For instance, Lavoie et al. (2013) emphasize the necessity to make better use of the data on groundwater resources for decision-making purposes. It is therefore argued that advances in 'globalized' research on groundwater stocks and flows should be more closely integrated into global, regional, and local water policies. There is evidence that detailed knowledge on groundwater resources can, for example, aid in developing viable instruments of economic regulation in the regions of freshwater scarcity (Esteban and Dinar 2013). Better integration of groundwater into decision-making will not only lead to the provision of more effective, research-informed policies but should also enhance the public recognition of the crucial role played by groundwater. Examples, such as the WHYMAP and IGRAC projects, should be more broadly utilized to achieve this goal. In this field, GIS methods are known as effective presentation, educational, and awareness raising tools due to the use of visual aids, such as maps and diagrams.

It is further argued that the issues of global groundwater stocks and flows should be better embedded into international policies on water management. These could aim at allocating specialized funds to developing countries that are often underlain by large aquifer systems with reduced groundwater monitoring networks. This would facilitate more research on groundwater storage and dynamics in the developing world, which in turn would provide reliable data to produce more accurate estimates of groundwater resources at different scales.

\section{Conclusions}

Freshwater is a crucial environmental resource. Despite its global importance, stocks and flows are yet poorly quantified and large discrepancies exist in the estimates provided by the available literature. Within the various freshwater compartments, groundwater constitutes a vital part of usable global freshwater resources, but its volume assessments have the highest levels of uncertainty. The current knowledge on global groundwater reserves is often based on the outcome of research conducted in the last century and very few recent studies exist. New and more precise assessment techniques should find broader scientific application to generate more reliable estimates of global groundwater stocks and flows. Limited knowledge on global groundwater resources may lead to inexact policy-making and managerial decisions. In particular, they may cause the development of ineffective measures and strategies directed to mitigate the growing human-induced impacts on the depletion and pollution of groundwater, thus hampering its sustainable management.

Rising global demands for groundwater require more investment in its characterization and assessment, thus calling for a new stream in existing water research. This new research stream should have a more pronounced focus on groundwater and management of its stocks and flows at all geographical levels, thus reflecting the concept of 'globalization.' The new, more groundwater-focused agenda should aim at enhancing the accuracy of estimates on groundwater stocks and flows at local, regional and global scales. This can be achieved via the broader application of the most up-to-date assessment methods, such as remote sensing techniques, gravimetric and isotope analysis, and high-precision modelling.

The establishment and regular maintenance of regional and global data collection networks should be an integral element of the new research agenda. These networks should compile the outcome of local and regional studies on groundwater systems alongside the human interventions made to them. The results of studies on local and regional groundwater resources should find better integration into national and international water policy-making and management. This will aid in translating research findings from theory to practice and enhancing the public awareness on the international importance of groundwater. Ultimately, this should lead to more responsible consumption of this vital environmental resource. 
Acknowledgments The ideas for this text originate from the chapter 'Water Taking Stock' in the book series 'Strüngmann Forum Report: Linkages of Sustainability' edited by Thomas E. Graedel and Ester van der Voet. This chapter was written as part of the 'Ernst Strüngmann Forum: Measuring Sustainability' (November 9-14, 2008) conference proceedings. We are grateful to two anonymous reviewers whose comments have helped us substantially improve this manuscript.

Open Access This article is distributed under the terms of the Creative Commons Attribution 4.0 International License (http://creative commons.org/licenses/by/4.0/), which permits unrestricted use, distribution, and reproduction in any medium, provided you give appropriate credit to the original author(s) and the source, provide a link to the Creative Commons license, and indicate if changes were made.

\section{References}

Agenda 21 (1992) Agenda 21: Rio declaration: forest principles: conference on environment and development: discussion documents, UN

Alcamo J, Döll P, Henrichs T, Kaspar F, Lehner B, Rosch T, Siebert S (2003) Global estimates of water withdrawals and availability under current and future "business-as-usual" conditions. Hydrol Sci J 48:339-348

Alley WM, Healy RW, LaBaugh JW, Reilly TE (2002) Flow and storage in groundwater systems. Science 296:1985-1990

Arnell NW (1999) A simple water balance model for the simulation of streamflow over a large geographic domain. J Hydrol 217:314-335

Arnell N (2002) Hydrology and global environmental change. Understanding global environmental change. Prentice Hall, Harlow

Balderacchi M, Benoit P, Cambier P, Eklo OM, Gargini A, Gemitzi A et al (2013) Groundwater pollution and quality monitoring approaches at the european level. Crit Rev Environ Sci Technol 43:323-408

Balek J (1989) Groundwater resources assessment. developments in water science. Elsevier, Amsterdam

Berner EK, Berner RA (1996) Global environment: water, air, and geochemical cycles. Prentice Hall, Upper Saddle River

Cash DW, Moser SC (2000) Linking global and local scales: designing dynamic assessment and management processes. Glob Environ Change 10:109-120

Charette MA, Smith WHF (2010) The volume of Earth's ocean. Oceanography 23:112-114

Chen C, Sawarieh A, Kalbacher T, Beinhorn M, Wang W, Kolditz O (2005) A GIS based 3-D hydrosystem model of the Zarqa Ma'inJiza areas in central Jordan. J Environ Hydrol 13:1-13

Christoffersen P, Bougamont M, Carter SP, Fricker HA, Tulaczyk S (2014) Significant groundwater contribution to Antarctic ice streams hydrologic budget. Geophys Res Lett 41:2003-2010

Diamond JM (2005) Collapse: how societies choose to fail or succeed. Penguin, New York

Döll P, Fiedler K (2008) Global-scale modeling of groundwater recharge. Hydrol Earth Syst Sci 12:863-885

Döll P, Kaspar F, Lehner B (2003) A global hydrological model for deriving water availability indicators: model tuning and validation. J Hydrol 270:105-134

Dragoni W, Sukhija BS (2008) Climate change and groundwater: a short review. Geol Soc (Lond) 288:12

Esteban E, Dinar A (2013) Modeling sustainable groundwater management: packaging and sequencing of policy interventions. J Environ Manag 119:93-102
Fazal MA, Kawachi T, Ichion E (2001) Extent and severity of ground-water arsenic contamination in Bangladesh. Water Int 26(3):370-379

Foster SSD, Chilton PJ (2003) Groundwater: the processes and global significance of aquifer degradation. Philos Trans of the Royal Soc of Lon Ser B 358:1957-1972

Freeze RA, Cherry JA (1979) Groundwater. Prentice-Hall, Englewood Cliffs

Frimpong Y, Oluwoye J, Crawford L (2003) Causes of delay and cost overruns in construction of groundwater projects in a developing countries; Ghana as a case study. Int $\mathbf{J}$ Proj Manag 21(5):321-326

Gleeson T, Wada Y, Bierkens MFP, van Beck LPH (2012) Water balance of global aquifers revealed by groundwater footprint. Nature 488:197-200

Gleeson T, Befus KM, Jasechko S et al (2015) The global volume and distribution of modern groundwater. Nat Geosci 9:161-167

Gleick PH (1993) water in Crisis: a guide to the world's fresh water resources. Oxford University Press, New York

Goldenberg S (2014) Why global water shortages pose threat of terror and war. The Observer. Accessed 9 Feb 2014

Gordalla BC, Ewers U, Frimmel FH (2013) Hydraulic fracturing: a toxicological threat for groundwater and drinking water? Environ Earth Sci 70(8):3875-3893

Green TR, Taniguchi M, Kooi H et al (2011) Beneath the surface of global change: impacts of climate change on groundwater. J Hydrol 405:532-560

Greenlee LF, Lawler DF, Freeman BD, Marrot B, Moulin P (2009) Reverse osmosis desalination: water sources, technology, and today's challenges. Water Res 43:2317-2348

Günter A, Schmidt R, Döll P (2007a) Supporting large-scale hydrogeological monitoring and modeling by time-variable gravity data. Hydrogeol J 15:167-170

Günter A, Stuck J, Werth S, Döll P, Verzano K, Merz B (2007b) A global analysis of temporal and spatial variations in continental water storage. Water Resour Res 43:1-19

Harzing AW, van der Wal R (2008) Google Scholar as a new source for citation analysis? Ethic Sci Environ Politc 8(1):61-73

Healy RW (2010) Estimating groundwater recharge. Cambridge University Press, Cambridge

Holman IP, Trawick P (2011) Developing adaptive capacity within groundwater abstraction management systems. J Environ Manag 92(6): 1542-1549

Hughes JD (2013) Energy: a reality check on the shale revolution. Nature 494:307-308

International Groundwater Resources Assessment Centre (IGRAC) (2015) http://www.un-igrac.org/. Accessed 7 Mar 2015

Jackson RE, Gorody AW, Mayer B et al (2013) Groundwater protection and unconventional gas extraction: the critical need for field-based hydrogeological research. Groundwater 51(4):488-510

Jacobson MC (2000) Earth system science: from biogeochemical cycles to global change. international geophysics series. Elsevier, San Diego

Jha MK, Chowdary VM (2007) Challenges of using RS and GIS in developing nations. Hydrogeol J 15:197-200

Jin S, Feng G (2014) Large-scale variations of global groundwater from satellite gravimetry and hydrological models, 2002-2012. Glob Planet Change 106:20-30

Jones JAA (1997) Global hydrology: processes, resources and environmental management. Longman, Harlow

Joyce RJ, Janowiak JE, Arkin PA, Xie P (2004) CMORPH: a method that produces global precipitation estimates from passive microwave and infrared data at high spatial and temporal resolution. J Hydrometeorol 5:487-503 
Klepper O, van Drecht G (1998) WARibaS, water assessment on a river basin scale: a computer program for calculating water demand and satisfaction on a catchment basin level for globalscale analysis of water stress. Report 402001009, The National Institute for Public Health and the Environment (RIVM), Bilthoven

Kumar GS (2002) Restriction Policy. GIS India 11(9):5-7

Lavoie R, Lebel A, Joerin F, Rodriguez MJ (2013) Integration of groundwater information into decision making for regional planning: a portrait for North America. J Environ Manag 114:496-504

Linton J (2004) Global hydrology and the construction of a water crisis. Gt Lakes Geogr 11(2):1-13

Llamas R (2003) Lessons learnt from the impact of the neglected role of groundwater in Spain's water policy. Dev Water Sci 50:63-81

Lvovitch MI (1970) World water balance: general report. In: symposium on world water balance. international association of scientific hydrology, pp 401-415

Marcinek J, Rosenkranz E, Saratka J (1996) Das Wasser der Erde: Eine geographische Meeres- und Gewässerkunde [The Water of the Earth: Marine and Hydrological Geography]. Perthes, Gotha

Margat J, van der Gun J (2013) Groundwater around the world: a geographical synopsis. CRC Press, London

Massmann JW, Madden M (1994) Estimating air conductivity and porosity from vadose-zone pumping tests. J Environ Eng 120(2):313-328

Mays LW (2013) Groundwater resources sustainability: past, present, and future. Water Resour Manage 27:4409-4424

Mook WG, de Vries JJ (2000) Environmental isotopes in the hydrological cycle: principles and applications. volume I: introduction-theory, methods, review. Vienna

Nace RL (1971) Scientific framework of world water balance. UNESCO Technical Papers on Hydrology, No. 7

Anonymous (2008) A fresh approach to water Nature 452:253

Oki T, Hanasaki N, Shen Y, Kanae S, Masuda K, Dirmeyer PA (2005) Global water balance estimated by land surface models participated in GSWP2. In : 85th AMS annual meeting, 8-14 January, 2005, San Diego

Palakodeti RC, LeBoeuf EJ, Clarke JH (2009) Tool for assessment of process importance at the groundwater/surface water interface. J Environ Manage 91:87-101

Pandey VP, Shrestha S, Chapagain SK, Kazama F (2011) A framework for measuring groundwater sustainability. Environ Sci Policy 14(4):396-407

Peterson BJ, Holmes RM, McClelland JW et al (2002) Increasing River Discharge to the Arctic Ocean. Science 298(5601): 2171-2173

Polak M , Klingbeil R , Struckmeier W (2007) Strategies for the sustainable management of non-renewable groundwater resources. hannover, federal institute for geosciences and natural resouces (BGR): 10

Post VEA, Groen J, Kooi H, Person M, Ge S, Edmunds WM (2013) Offshore freshwater groundwater reserves as a global phenomenon. Nature 504:71-78

Potter TD, Colman BR (2003) Handbook of weather, climate, and water: atmospheric chemistry, hydrology, and societal impacts. Wiley, Hoboken

Rahman A (2008) A GIS based DRASTIC model for assessing groundwater vulnerability in shallow aquifer in Aligarh, India. Appl Geogr 28:32-53

Rodell M, Famiglietti JS (2002) The potential for satellite-based monitoring of groundwater storage changes using GRACE: the High Plains aquifer. Central US. J Hydrol 263:245-256

Schwartz FW, Zhang H (2003) Fundamentals of ground water. Wiley, New York
Seiler K-P, Gat JR (2007) Groundwater recharge from run-off, infiltration and percolation. Springer Verlag, Water science and technology library. Dordrecht

Shiklomanov IA (1996) Assessment of water resources and availability throughout the world. State Hydrological Institute, St. Petersburg

Shiklomanov IA (1997) Comprehensive assessment of the freshwater resources of the world: assessment of water resources and water availability in the world. World Meteorological Organization, Geneva

Shiklomanov IA, Rodda JC (2003) World water resources at the beginning of the 21st century. Cambridge University Press, International hydrology series. Cambridge

Sophocleous M (2002) Interactions between groundwater and surface water: the state of the science. Hydrogeol J 10:52-67

Sparks EL, Cebrian J, Tobias CR, May CA (2015) Groundwater nitrogen processing in Nothern Gulf of Mexico restored marches. J Environ Manage 150:206-215

Struckmeier W, Richts A (2006) WHYMAP and the World Map of Transboundary Aquifer Systems at the scale of 1:50 000000 (Special Edition for the 4th World Water Forum, Mexico City, March 2006). Episodes 29:274-278

Struckmeier W, Richts A (2008) Groundwater Resources of the World (Global map at scale of 1:25000 000. UNESCO/BGR). In: W. Struckmeier and A. Richts (Eds). UNESCO/BGR, Paris/ Hannover

Stuart ME (2011) Potential groundwater impact from exploitation of shale gas in the UK. British Geological Survey Open Report, OR/12/001. http://nora.nerc.ac.uk/16467/1/OR12001.pdf. Accessed 7 mar 2015

Uhlenbrook S (2007) Biofuel and water cycle dynamics: what are the related challenges for hydrological processes research? Hydrol Process 21(26):3647-3650

UNEP (2008) vital water graphics. an overview of the state of the world's fresh and marine waters. 2nd edition, United Nations Environment Programme. http://www.unep.org/dewa/vitalwater. Accessed 7 mar 2015

UNESCO (2012) Groundwater and global change: trends, opportunities and challenges. UNESCO, Paris

United Nations Children's Fund-UNICEF and World Health Organisation (2012) Progress on Drinking Water and Sanitation, 2012 Update, 2012. http://www.unicef.org/media/files/JMPreport2012. pdf. Accessed 7 mar 2015

United Nations Educational, Scientific and Cultural Organisation UNESCO (2003) Water for people, water for life: the United Nations world water development report. UNESCO, Paris

van der Gun J (2012) Groundwater and global change: trends, opportunities and challenges, Side Publication Series. UNESCO, Paris

van der Leeden F (1975) Water resources of the world: selected statistics. Water Information Center, Port Washington

van Geldern R, Hayashi T, Boettcher ME et al (2013) Stable isotope geochemistry of pore waters and marine sediments from the New Jersey shelf: methane formation and fluid origin. Geosphere 9:96-112

van Geldern R, Baier A, Subert HL et al (2014) Pleistocene paleogroundwater as a pristine fresh water resource in southern Germany-Evidence from stable and radiogenic isotopes. Sci Total Environ 496:107-115

Verdin KL, Verdin JP (1999) A topological system for delineation and codification of the Earth's river basins. J Hydrol 218(1-2):1-12

Vörösmarty C, Lettenmaier D, Leveque C, Meybeck M, Pahl-Wostl C et al (2004) Humans transforming the global water system. EOS, Transactions American Geophysical Union. 85:513-516 
Wada Y, van Beek LPH, van Kempen CM, Reckman JWTM, Vasak S, Bierkens MFP (2010) Global depletion of groundwater resources. Geophys Res Lett 37:1-5

Wada Y, Wisser D, Bierkens MFP (2014) Global modelling of withdrawal, allocation and consumptive use of surface water and groundwater resources. Earth Syst Dyn 5:15-40

Welsh WD (2007) Groundwater balance modelling with Darcy's law. Australian National University (http://thesis.anu.edu.au/public/ adt-ANU20070703.165654/index.html). Accessed 7 mar 2015

Widen-Nilsson E, Halldin S, Xu C (2007) Global water-balance modelling with WASMOD-M: parameter estimation and regionalisation. J Hydrol 340:105-118
World Business Council for Sustainable Development-WBCSD (2005) Global map of water 2005 access to safe drinking water and sanitation. Maplecroft, Bradford-on-Avon

Yates DN (1997) Approaches to continental scale runoff for integrated assessment models. J Hydrol 201:289-310

Younger PL (2014) Hydrogeological challenges in a low-carbon economy. Q J Eng GeolHydrogeol 47:7-27

Zektser IS, Everett LG (2004) Groundwater resources of the world and their use. UNESCO Series on Groundwater 6. Paris: UNESCO 